ANDRZEJ SZABACIUK

Katolicki Uniwersytet Lubelski Jana Pawła II

DOI : $10.14746 /$ rie.2017.11.22

\title{
Migracje z Europy Wschodniej - szanse i zagrożenia dla Unii Europejskiej
}

Migracje przymusowe i wyjazdy w poszukiwaniu lepszych warunków bytowych stanowią immanentny element niezwykle zróżnicowanej i wielowątkowej historii Europy. Przez stulecia miliony Europejczyków kolonizowało zamorskie terytoria zależne, osiedlało się praktycznie na wszystkich kontynentach, tworząc nowe organizmy państwowe - politycznie, kulturowo i gospodarczo związane z Europą. Wraz z rewolucją przemysłową w Anglii, stopniowo rozlewającą się na cały Stary Kontynent i z czasem poza jego obszar, znacząco wrosły różnice w rozwoju poszczególnych regionów, co stymulowało migracje zarobkowe do lepiej rozwiniętych i bogatszych państw. Najczęściej były to wyjazdy sezonowe, które na masową skalę zaczęły się w XIX w., gastarbeiterzy przeważnie szukali zatrudnienia $\mathrm{w}$ rolnictwie $\mathrm{w}$ bogatszych regionach europejskich, w szczególności w Niemczech czy Francji. W przypadku wyjazdów za ocean, z reguły osiedlano się na stałe, próbując na nowo ułożyć sobie życie (Castles, Miller, 2011, s. 107-126).

Wielka Wojna, która pochłonęła miliony istnień ludzkich, zahamowała te procesy, a II wojna światowa i gwałtowne przekształcenia dekolonizacyjne przyniosły diametralne zmiany w europejskim systemie sieci migracyjnych. Przypływy migracyjne zaczęły stopniowo dominować nad odpływami. Sprzyjała temu postępująca stabilizacja polityczna kontynentu europejskiego oraz rosnący dobrobyt, będący konsekwencją praktycznej realizacji amerykańskiej doktryny powstrzymywania poprzez szeroką implementację planu pomocowego George'a Marshalla. Sukces projektu europejskiego oraz zmiany społeczne zachodzące w większości państw wysoko rozwiniętych, sprawiły, że stale rosło zapotrzebowanie na pracowników z zagranicy, którzy byli w stanie wypełnić niedobory na rynku pracy. Początkowo jako panaceum na chroniczne problemy braku wolnych rąk do pracy, szczególnie w sektorach mało atrakcyjnych z punktu widzenia rodzimych pracowników, postulowano sprowadzanie pracowników tymczasowych z dawnych kolonii, ewentualnie z państw powiązanych z państwami imigracyjnymi zależnościami historycznymi, kulturowymi, gospodarczymi lub politycznymi. Szybko okazało się jednak, że duża część imigrantów tymczasowych czy cyrkulacyjnych decydowała się na osiedlenie na stałe, co więcej, w miarę możliwości zabiegała o sprowadzenie rodzin. Proces ten był wyraźnie widoczny po kryzysie naftowym z 1973 r. (Banaś, 2010, s. 55-60). Sprzeczne interesy pracodawców, którym zależało na zatrzymaniu wyszkolonego i wysoko zmotywowanego pracownika zza granicy oraz państw imigracyjnych, które w procesie konceptualizacji i implementacji polityki migracyjnej dążyły do uzyskania możliwie dużej kontroli nad strumieniami migracyjnymi trafiającymi i wypływającymi z Europy, na dłuższą metę nie były do 
pogodzenia. Masowy charakter imigracji zarobkowej do Europy oraz ograniczenia związane z zobowiązaniami międzynarodowymi $\mathrm{w}$ zakresie polityki humanitarnej, znacząco ograniczyły możliwości działania i instrumentarium polityki migracyjnej poszczególnych państw.

Burzliwe wydarzenia związane z tzw. Arabską Wiosną zdestabilizowały sytuację polityczną w państwach Bliskiego Wschodu i Afryki Północnej (ang. MENA) i wywołały masową migrację ludności uciekającej przed przedłużającymi się konfliktami wewnętrznymi o silnym zabarwieniu etnicznym i religijnym. Zdesperowani mieszkańcy Syrii, Iraku i Libii w dramatycznych okolicznościach porzucili domostwa, poszukując bezpiecznego schronienia w państwach sąsiednich. Nieliczni, najczęściej lepiej sytuowani, decydowali się na dalszą podróż, głównie do Unii Europejskiej. Do tej grupy przyłączyły się także osoby, które postanowiły wykorzystać sytuację do nielegalnego przekroczenia granicy strefy Schengen. W konsekwencji elity europejskie muszą mierzyć się z tzw. kryzysem migracyjnym, który obok Brexitu jest jednym z kluczowych tematów debat w instytucjach unijnych (Townsend, 2015, s. 2-139). Polaryzacja powstała wokół wspomnianej kwestii budzi ogromne emocje. Wypracowanie odpowiedniego mechanizmu zarządzania strumieniami uchodźczymi i migracyjnymi oraz rozwiązanie kwestii relokacji, a w dalszej kolejności także integracji uchodźców/imigrantów, będą miały istotny wpływ na kondycję zjednoczonej Europy w przyszłości.

Jednocześnie obserwujemy nowe zjawisko - masowy napływ imigrantów krótkookresowych i cyrkulacyjnych z Europy Wschodniej, głównie z Ukrainy. Emigracja zarobkowa z Ukrainy wiąże się głównie z trudną sytuacją społeczno-gospodarczą naszego wschodniego sąsiada wywołaną przez wielopłaszczyznową wojnę hybrydową z Federacją Rosyjską oraz bolesny proces transformacji po Rewolucji Godności. Obecnie ważnym czynnikiem zachęcającym do wyjazdów jest również liberalna polityka migracyjna Polski wobec części państw regionu oraz reżim bezwizowy, którym objęte zostały Ukraina, Mołdawia i Gruzja.

Celem artykułu jest analiza sytuacji migracyjnej współczesnej Europy na tle dynamicznych zmian obserwowanych w jej najbliższym sąsiedztwie w ostatnich latach. W kontekście tych rozważań pokrótce przybliżono genezę, przebieg oraz skutki masowego napływu imigrantów/uchodźców z Południa, koncentrując się następnie na często pomijanym problemie imigracji zarobkowej z Europy Wschodniej. Kwestia ta jest szczególnie ważna z punktu widzenia Polski m.in. ze względu na jej położenie geograficzne oraz burzliwy przebieg przekształceń politycznych i społeczno-gospodarczych obserwowanych za wschodnią granicą. Warto poddać ją wnikliwej analizie także z powodu dynamiki procesów migracyjnych z kierunku wschodniego oraz ich potencjalnego wpływu na sytuację państw docelowych migracji zarobkowej. Przygotowując artykuł posługiwaliśmy się metodą porównawczą z elementami metody instytucjonalno-prawnej.

\section{Unia Europejska wobec współczesnych wyzwań migracyjnych}

Na przełomie XX i XXI wieku procesy migracyjne są z jednej strony produktem globalizacji i procesów społeczno-politycznych z nią powiązanych, z drugiej same stymulują i pogłębiają globalizację oraz dekompozycję państw narodowych. Europa Za- 
chodnia, obok Stanów Zjednoczonych i Federacji Rosyjskiej jest jedną z kluczowych destynacji globalnych strumieni migracyjnych. Na przestrzeni ostatnich dekad możemy zaobserwować systematycznie rosnącą liczbę osób decydujących się na migrację w tych kierunkach głównie z powodów ekonomicznych. Według wyliczeń ONZ w 2000 r. na świecie żyło ok. 173 mln migrantów, którzy osiedlali się przede wszystkim w państwach wysokorozwiniętych, w 2015 roku liczba ta wzrosła do $244 \mathrm{mln}$. Najwięcej zamieszkuje Europę i Azję - odpowiednio 76 i $75 \mathrm{mln}$ (UN, 2016, s. 4-9). W szczególnie trudnym położeniu znajduje się Europa sąsiadująca z dwoma niestabilnymi i niezwykle ludnymi regionami: Afryką Północną i Bliskim Wschodem. Obecnie obserwowane migracje z tych kierunków są najprawdopodobniej zaledwie początkiem nowej masowej fali migracji z Południa, którą w przyszłości stymulował będzie dynamiczny przyrost naturalny państw Afryki i Bliskiego Wschodu, problemy wewnętrzne miejscowych gospodarek, zmiany klimatyczne, których efektem będzie głód i niedobory wody pitnej, ekspansja fundamentalizmu islamskiego i powiązane $\mathrm{z}$ nią konflikty etnoreligijne (Romagnoli, 2013, s. 172-195). Państwa Unii Europejskiej muszą mieć świadomość skali i dynamiki tych procesów i zawczasu wypracować odpowiednie instrumenty łagodzące niekorzystne ich następstwa. Do tego potrzebna jest solidarność oraz długofalowa i konsekwentnie implementowana europejska polityka sąsiedztwa (European, 2015).

Z drugiej strony poważnym wyzwaniem jest kryzys demograficzny obserwowany w większości państw europejskich. W okresie od 1994 do 2005 r. wskaźnik żywych narodzin przypadających na jedną kobietę w wieku reprodukcyjnym w Europie średnio kształtował się na poziomie 1,45. Chociaż obecnie sytuacja nieco poprawiła się, to nadal w większości państw europejskich nie udało się przekroczyć poziomu 2,1 żywych narodzin, co zapewniłoby wymienność pokoleń. Dodajmy też, że niewielka poprawa dzietności zazwyczaj nie łączy się ze zmianą trendów demograficznych wśród rdzennej populacji europejskiej, a stanowi najczęściej wynik dużej dzietności osób wywodzących się ze środowisk imigranckich. Mała dzietność rdzennych Europejczyków jest przede wszystkim konsekwencją przekładania decyzji o macierzyństwie: w ponad połowie państw członkowskich Unii Europejskiej średnia narodzin pierwszego dziecka oscyluje wokół 30 roku życia kobiety. Przyczyn tego stanu rzeczy jest wiele, m.in. przedłużająca się edukacja, problemy ze znalezieniem pracy po studiach, zmiany zachodzące w procesie formalizowania związków, rosnąca indywidualizacja, świadome planowanie macierzyństwa (Neyer, Andersson, Kulu, 2013, s. 2-4).

W konsekwencji postępuje proces starzenia się społeczeństw państw europejskich. Pod tym względem sytuacja Starego Kontynentu przedstawia się zdecydowanie najgorzej na tle innych regionów świata. W ostatnich latach procentowy stosunek osób starszych niż 65 lat do populacji w wieku produkcyjnym (16-64) to średnio 25 do $75 \%$, kiedy na innych kontynentach czy w subregionach jest zdecydowanie niższy niż 20\%. Szacuje się jednak, że jeżeli obecne tendencje demograficzne utrzymają się, wówczas w 2050 r. wyżej przytoczone proporcje ulegną wyraźnej zmianie na korzyść osób starszych: 47 do 53\%. Oznaczało to będzie, że na jednego mieszkańca na emeryturze przypadnie mniej więcej jedna osoba czynna zawodowo (Rau, Muszyńska, Vaupel, 2013, s. 119-120). Oczywiście w rzeczywistości sytuacja może wyglądać jeszcze gorzej, gdyż do pierwszej kategorii doliczyć należy osoby nieczynne zawodowo w wieku poniżej 65 roku życia. 
Janusz Balicki podkreśla, że do odwrócenia wyżej nakreślonych trendów demograficznych konieczna jest masowa, kilkusetmilionowa imigracja zarobkowa. Bez niej utrzymanie dotychczasowej liczby ludności, a przede wszystkim odpowiedniego odsetka osób czynnych zawodowo, nie będzie możliwe. Brak wymienności pokoleń oraz niedobory siły roboczej istotnie wpłyną na efektywności i konkurencyjność gospodarek europejskich oraz na system ubezpieczeń społecznych oparty w większości państw regionu na solidarności pokoleń (Balicki, Stalker, 2006, s. 140-147). W tym aspekcie kontrolowana migracja zarobkowa sprzyjać może rozwojowi gospodarczemu państw, zapewniając napływ imigrantów zarobkowych do europejskich przedsiębiorstw, jednak różnice kulturowe i problemy integracyjne budzą niepokój obywateli większości państw europejskich i stymulują wzrost nastrojów antyimigranckich i ksenofobicznych. Niejednokrotnie podsycane są one przez populistycznych polityków czy nieodpowiedzialnych dziennikarzy szukających taniej sensacji. Częstym tematem debat politycznych i publicystycznych są odmienne stroje (np. burki czy hidżaby), małżeństwa z nieletnimi, poligamia, okaleczania narządów płciowych, zabójstwa „honorowe”. Z badań World Values Survey z lat 2005-2009 wynika, że najbardziej ksenofobicznym państwem europejskim jest Francja, aż 36,5\% Francuzów nie życzy sobie imigrantów w sąsiedztwie, podobny stosunek deklaruje 28,5\% Czechów, 23,80\% Węgrów, 22,8\% Austriaków, 16,30\% Rumunów, 15,9\% Finów, 14,2\% Brytyjczyków, 13,7\% Polaków i 13,3\% Niemców. Z drugiej strony zaledwie 1,8\% Szwedów prezentowało takie poglądy (World Values Survey 2005-2009, s. 67).

Destabilizacja państw MENA i masowy napływ uchodźców i imigrantów z tego kierunku wzmocniły obawy mieszkańców niektórych państw europejskich. Kolejna tura badań przeprowadzonych przez World Values Survey w latach 2010-2014 pokazała wzrost nastrojów antyimigranckich w niektórych państwach Unii Europejskiej. Przykładowo w Niemczech liczba osób niechętnych wobec imigrantów zwiększyła się do 21.3\%, w Rumuni do 21,3\%. Jednocześnie w Austrii odsetek ten spadł do 10,5\%, a w Polsce do 7,2\% (World Values Survey 2010-2014, s. 72). Trudno jest jednoznacznie stwierdzić czy przytaczane różnice stanowią konsekwencję braku miarodajności badań, czy też inne czynniki wpłynęły na zmianę postrzegania problemu przyjmowania imigrantów/uchodźców. Warto zwrócić jednak uwagę, iż w Polsce od lat utrzymuje się duży odsetek respondentów niechętnie odnoszących się do imigrantów i przeciwnych przyjmowaniu uchodźców, nawet z państw objętych konfliktami zbrojnymi. Badania CBOS ze stycznia 2017 r. pokazują, że aż 54\% respondentów prezentuje takie stanowisko. Zauważmy jednak, że występuje duża polaryzacja w zależności od państwa pochodzenia uchodźców: tylko $28 \%$ respondentów zgodziłoby się przyjąc część uchodźców z Bliskiego Wschodu i Afryki, ale jednocześnie 58\% deklaruje chęć przyjęcia uchodźców/imigrantów ekonomicznych z Ukrainy (Stosunek, 2017, s. 3-11).

Osoby niechętne przyjmowaniu uchodźców czy imigrantów najczęściej usprawiedliwiają się względami bezpieczeństwa. Przy czym zdecydowana większość argumentów podnoszonych w tym kontekście opiera się o uprzedzenia i półprawdy powielane przez środki masowego przekazu i media społecznościowe. Jedną z najczęściej powtarzanych manipulacji jest łączenie masowej imigracji ze wzrostem przestępczości. Szczegółowe badania tej kwestii, prowadzone przez uznane ośrodki analityczne dowodzą, że imigracja zarobkowa z reguły nie wpływa na wzrost liczby przestępstw 
w społeczeństwie przyjmującym. Co więcej, niektóre analizy dowodzą, że migracja może sprzyjać spadkowi liczby przestępstw - taka sytuacja miała miejsce np. w Wielkiej Brytanii w regionach zamieszkiwanych przez imigrantów z Europy Wschodniej, gdzie zmniejszyła się liczba włamań. Podobnie często nierzetelne są argumenty o zagrożeniu bezpieczeństwa ekonomicznego, wyzyskiwaniu przez przybyszów z zagranicy pomocy społecznej oraz oszustwach podatkowych. Przykładowo nieoficjalne dane brytyjskiego Home Office dowodza, że nowi imigranci z Europy Wschodniej znacznie rzadziej wyłudzają zasiłki i nie płacą podatków niż osoby urodzone w Wielkiej Brytanii. Podobnie niezgodne $\mathrm{z}$ prawdą są twierdzenia sugerujące, że migranci odbierają rdzennej ludności pracę oraz nadmiernie obciążają instytucje publiczne, w tym szpitale i szkoły. W rzeczywistości najczęściej zajmują najgorzej płatne i mało atrakcyjne stanowiska, które nie znajdują się w orbicie zainteresowań miejscowej ludności, a ponieważ w ogromnej większości płacą podatki, łożą także na utrzymanie placówek publicznych (Dearden, 2016, s. 5).

Oczywiście nie wszystkie obawy społeczeństw przyjmujących są nieuzasadnione. Migracje mogą nieść ze sobą szereg zagrożeń czy też wyzwań z punktu widzenia polityk publicznych. Najszerzej komentowanym i budzącym najwięcej emocji jest zagrożenie terrorystyczne będące konsekwencją działalności salafickiego ruchu globalnego dżihadu. Szczególnie dużo uwagi zaczęto do niego przywiązywać po dramatycznych wydarzeniach z 11 września 2001 r. - od tego przełomowego momentu coraz częściej dostrzegano związek relacyjny zachodzący między migracjami międzynarodowymi a globalną siatką terrorystyczną (Wejkszner, 2014, s. 227-234).

Stale rosnąca skala migracji międzynarodowych niesie ze sobą także szereg innych zagrożeń, m.in. przemyt ludzi powiązany z nierejestrowaną imigracją, handel żywym towarem, przemyt narkotyków, handel bronią, handel nielegalnie pozyskanymi działami sztuki, kosztownościami itp. Masowe ruchy ludnościowe sprzyjają też działalności zorganizowanej przestępczości etnicznej. W najtrudniejszej sytuacji znajdują się imigranci nieregularni, którzy podejmują pracę w gospodarce nieformalnej. Często pozbawieni opieki państwa pracują ponad siły za znacznie zaniżone stawki lub w skrajnych wypadkach za jedzenie i dach nad głową. Zorganizowane grupy przestępcze wykorzystują ich trudne położenie, czerpiąc korzyści z pracy niewolniczej lub prostytucji. Brak znajomości języka i słaba integracja ze społeczeństwem przyjmującym oraz zamknięty charakter części wspólnot imigranckich utrudniają walkę z tym procederem (Leman, Janssens, 2015, s. 62-132).

Ożywiona dyskusja prowadzona od dekad na temat zagrożeń i korzyści wynikających z migracji międzynarodowych łączy się bezpośrednio z zagadnieniem roli polityki migracyjnej Unii Europejskiej w kontekście diametralnych zmian zachodzących w najbliższym sąsiedztwie zjednoczonej Europy. W toku budzących wiele emocji debat ścierają się często radykalnie sprzeczne poglądy na kształt wspólnotowej polityki w tym aspekcie. Część polityków europejskich stoi na stanowisku, że konieczne jest ograniczenie fali imigracji zarobkowej, ponieważ niekontrolowany napływ imigrantów z innych kręgów kulturowych przynosi więcej problemów niż korzyści. Inni podkreślają, że obserwowane od dziesięcioleci, przywołane wyżej tendencje demograficzne, wymuszają na Europie większą otwartość na imigrantów ekonomicznych - liberalizacja polityki migracyjnej jest również zgodna z linią polityki humanitarnej obranej 
przez większość dojrzałych demokracji. Wiele kontrowersji budzi także dyskusja na temat zakresu wspólnotowej polityki migracyjnej oraz jej nadrzędność wobec polityk migracyjnych poszczególnych państw członkowskich UE. Wspólna unijna polityka migracyjna jest naturalnym następstwem pogłębiania integracji europejskiej, przez co silnie łączy się z problemem wizji przyszłości zjednoczonej Europy (Brzozowski, 2011, s. 51-56).

Wypracowanie podstaw prawnych układu z Schengen z 1985 r. oraz podpisanie w 1986 r. Jednolitego Aktu Europejskiego, zakładającego stopniowe tworzenie rynku wewnętrznego w obrębie Europejskiej Wspólnoty Gospodarczej, dały impuls do wypracowania nowych, znacznie bardziej szczegółowych założeń polityki migracyjnej na poziomie Wspólnot Europejskich. Swobodny przepływ ludzi, towarów i usług w ramach państw strefy Schengen wymuszał opracowanie nowego modelu zarządzania strumieniami imigracyjnymi oraz jednolitego systemu ochrony granic zewnętrznych. Wspólnych regulacji wymagała również polityka wobec imigrantów zarobkowych, polityka wobec uchodźców oraz kwestia łączenia rodzin. Te problemy starano się dopracować w kolejnych dokumentach przygotowanych w następnych latach, m.in. w konwencji dublińskiej z 1990 r. (weszła w życie w 1997 r.) wraz z jej dwiema modyfikacjami, traktacie z Maastricht, traktacie amsterdamskim oraz traktacie lizbońskim (Brzozowski, 2011, s. 67-71).

Masowy napływ uchodźców i imigrantów zarobkowych z państw MENA po $2010 \mathrm{r}$. wystawił na próbę dotychczasową politykę migracyjną UE. Nowe rozwiązania, w tym budzący wiele kontrowersji system relokacji uchodźców, spotykają się z oporem nie tylko państw Europy Środkowej. Zataczająca coraz szersze kręgi debata o polityce migracyjnej dotyka coraz częściej także problemu integracji migrantów, problemu gettyzacji oraz zmian zachodzaccych w składzie religijnym i etnicznym we współczesnej Europie. Warto jednak podkreślić, że roztaczana przez część populistycznych polityków czy publicystów wizja pełnej islamizacji Europy w perspektywie kilku dziesięcioleci jest mało prawdopodobna. Analiza przekształceń ludnościowych w skali globalnej przygotowana przez Pew Research Center dowodzi, że do 2050 r. liczba muzułmanów w Europie wzrośnie o 12,5\%, kiedy populacja chrześcijan powiększy się o 25,3\% (The Future, 2015, s. 151). Warto jednak podkreślić, że trafność tej prognozy w dużym stopniu zależała będzie od wielkości strumieni migracyjnych docierających do Europy z Południa.

\section{Potencjal migracyjny państw Europy Wschodniej w kontekście liberalizacji reżimu wizowego}

Okres stopniowej dekompozycji Związku Sowieckiego przyniósł ze sobą daleko idące zmiany w życiu milionów mieszkańców obszaru poradzieckiego. Procesy migracyjne w regionie, które wcześniej klasyfikowano jako migracje wewnętrzne, po 1991 r. zaczęto klasyfikować jako migracje międzynarodowe, co w niektórych aspektach utrudniało przemieszczanie się po obszarze poradzieckim, z drugiej jednak strony zniesiono cześć restrykcji uniemożliwiających wcześniej migrację wewnętrzną, co wywołało nową walę wyjazdów w obrębie poszczególnych państw, a także migracje 
międzynarodowe. Znacznie uproszczono także emigrację z regionu, co wykorzystało kilka milionów Żydów, Niemców, Greków i Armeńczyków, których wyjazdy umożliwiało wsparcie licznej diaspory. Zdecydowana większość migrantów z państw poradzieckich poruszała się w dalszym ciągu w obrębie dawnych republik, a najliczniejsze strumienie migracyjne kierowały się do europejskiej części Federacji Rosyjskiej, głównie do wielkich metropolii, tj. Moskwy i Petersburga. Sprzyjało to wzrostowi dysproporcji w rozwoju poszczególnych obszarów dawnego państwa związkowego.

Pierwsza dekada po upadku ZSRR była czasem powtarzających się kryzysów ekonomicznych i politycznych destabilizujących region posowiecki. Zmiany w polityce wewnętrznej części państw prowadziły do wyraźnego wzrostu nastrojów ksenofobicznych, co skutkowało wzrostem liczby krwawych konfliktów etnicznych (m.in. w Czeczeni, Tadżykistanie, Azerbejdżanie). Konsekwencją była masowa migracja przymusowa populacji rosyjskojęzycznej oraz osób, które uciekały przed konfliktami zbrojnymi lub dyskryminacyjną polityką nowych władz. Szacuje się, że w latach 1990-2003 do Federacji Rosyjskiej przyjechało 8,2 mln osób, wśród których przeważali Rosjanie lub osoby rosyjskojęzyczne (Танги, 2012, s. 386-387).

Po 2000 r. pojawił się nowy trend. Dobra koniunktura na rynku surowców energetycznych przyczyniła się do wyraźnego ożywienia gospodarczego Federacji Rosyjskiej. Dzięki petrodolarom i inwestycjom zachodnich koncernów w wielkich metropoliach rosyjskich szybko rosły zarobki i poprawiał się poziom życia zwykłych mieszkańców. Rosło także zapotrzebowanie na siłę roboczą z zagranicy - zarówno specjalistów, jak i tymczasowych gastarbeiterów. W konsekwencji, szczególnie do Moskwy, napływały miliony osób w poszukiwaniu lepszego życia. Obowiązujący w ramach Wspólnoty Niepodległych Państw reżim bezwizowy ułatwiał wjazd do Federacji Rosyjskiej, a rozbudowana gospodarka nieformalna umożliwiała znalezienie zatrudnienia w szarej strefie. Brak skutecznego systemu kontroli strumieni migracyjnych oraz wszechobecna korupcja ograniczały skuteczność rosyjskiej polityki migracyjnej, co rodziło frustrację zwykłych mieszkańców Rosji. Coraz powszechniejsze były nastroje antyemigracyjne. Gwałtowny ich wzrost przyniósł kryzys finansowy z 2008 r., który mocno odbił się na kondycji rosyjskiej gospodarki. Władze na czele z prezydentem Władimirem Putinem wprowadziły szereg nowych przepisów, które miały ograniczyć nierejestrowaną imigrację zarobkową. Od 2010 r. ustanowiono limity na zaproszenia do pracy oraz pozwolenia na pracę - ustalane odgórnie przez władze federalne w zależności od potrzeb poszczególnych podmiotów federalnych. Największe limity uzyskały okręgi w azjatyckiej części Rosji, najmniejsze w części europejskiej. Uzupełnieniem tego systemu były patenty na pracę, które można było wykupić i podjąć pracę w dowolnym miejscu Rosji, ale wyłącznie w charakterze pomocy domowej lub w rolnictwie (Szabaciuk, 2014, s. 97-98).

Reforma prawa migracyjnego nie przyniosła oczekiwanych rezultatów, ponieważ w dalszym ciagu imigranci z WNP przenikali bez większych przeszkód do gospodarki nieformalnej. $Z$ tej przyczyny władze federalne postanowiły wprowadzić dodatkowe ograniczenia. Od 1 stycznia 2014 r. obywatele państw WNP mogli przebywać na terytorium Federacji Rosyjskiej legalnie bez wizy maksymalnie do 3 miesięcy w ciagu 180 dni. Wcześniej obowiązujące przepisy pozwalały na legalny pobyt osobom bez wiz pracowniczych, które raz na trzy miesiące opuściły terytorium federalne nawet na 
jeden dzień. Najczęściej nieregularni migranci udawali się do najbliższego punktu granicznego i po jego przekroczeniu wracali z powrotem do Rosji (Федеральный, 2013). Nowe regulacje były poważnym utrudnieniem, tym bardziej, że za naruszenie terminu trzymiesięcznego pobytu grozi nawet dziesięcioletni zakaz wjazdu do Rosji. Kolejnym novum była modyfikacja systemu patentowego, od 1 stycznia 2015 r. obowiązywał on wszystkich obywateli państw objętych reżimem bezwizowym, dodatkowo znacznie poszerzono listę wykonywanych zawodów. Obywatele państw WNP, jakie nie weszły do Eurazjatyckiej Unii Gospodarczej, musieli nie tylko wykupić patent, którego cena ustalana była przez określone podmioty federalne, ale nałożono na nich także obowiązek zaliczenia egzaminu integracyjnego z języka rosyjskiego, historii i elementów prawa (Szabaciuk, 2016, s. 231-233).

Zmiany te zbiegły się z eskalacją konfliktu na Ukrainie, który negatywnie odbił się na wizerunku międzynarodowym Federacji Rosyjskiej, co miało bezpośredni wpływ także na jej sytuację gospodarczą. Masowy odpływ inwestorów zagranicznych, spadek cen surowców węglowodorowych na rynkach globalnych, problemy finansowe wywołane sankcjami, wzrost kosztów utrzymania w efekcie wprowadzonego embarga na europejskie produkty spożywcze - to wszystko odcisnęło się negatywnie na sytuacji gastarbeiterów pracujących w Federacji Rosyjskiej. Dodatkowo opłacalność imigracji zarobkowej znacząco zmalała na skutek załamania się kursu rubla w stosunku do dolara. W konsekwencji wiele osób zdecydowało się na powrót do domu, inni próbowali emigrować w innym kierunku. Nie znamy precyzyjnych statystyk obrazujących skalę zjawiska, szacuje się jednak, że na wyjazd mogło zdecydować się nawet do 30\% imigrantów zarobkowych, z których sporą część stanowili obywatele państw Europy Wschodniej (Szabaciuk, 2016, s. 234-235).

Nowa rosyjska polityka migracyjna oraz załamanie gospodarcze, obserwowane na obszarze poradzieckim od eskalacji konfliktu ukraińsko-rosyjskiego, miały istotny wpływ na kształt procesów migracyjnych w regionie. Obywatele państw, które miały realną możliwość wyboru kierunków emigracji, dzięki rozbudowanym sieciom migracyjnym, szukali innych państw imigracyjnych. Najpopularniejszym kierunkiem były wyjazdy do Unii Europejskiej. Największe możliwości dywersyfikacyjne mają w tym względzie Ukraińcy, którzy posiadają liczną diasporę w Europie Zachodniej oraz w Ameryce Północnej. Obecnie najczęściej wybieranym państwem docelowym ukraińskiej emigracji zarobkowej jest Polska. Wynika to przede wszystkim z wprowadzonej już w 2006 r. uproszczonej procedury legalizowania zatrudniania osób z 6 państw Europy Wschodniej (Ukraina, Mołdawia, Białoruś, Gruzja, Rosja i Armenia). W świetle wspomnianych przepisów - kilkakrotnie modyfikowanych i liberalizowanych - polski pracodawca, których chce zatrudniać obywatela jednego z wyżej wymienionych państw (na łączny okres do 6 miesięcy w ciągu roku), musi złożyć odpowiednie oświadczenie w powiatowym Urzędzie Pracy. Najczęściej z takiej możliwości korzystali właśnie obywatele Ukrainy, którzy podejmowali pracę głównie w usługach, w branży budowlanej czy w rolnictwie. Kryzys ukraiński i deprecjacja hrywny sprawiły, że liczba zainteresowanych wyjazdem na Zachód wzrosła. Szacuje się, że w Polsce może pracować ponad $1 \mathrm{mln}$ obywateli Ukrainy, jednak krótkoterminowy charakter pracy sprawia, że na terytorium Polski nie przebywa jednocześnie więcej niż 500 tys. osób (Chmielewska, Dobroczek, Puzynkiewicz, 2016, s. 6). Dzięki danym z Minister- 
stwa Rodziny, Pracy i Polityki Społecznej z 2016 r. wiemy, że w Urzędach Pracy polscy pracodawcy złożyli aż 1262845 oświadczeń o zamiarze zatrudnienia obywatela Ukrainy, w całym 2015 r. zarejestrowano ich 762 700, zauważmy jednak, że jeszcze w 2013 r. było ich zaledwie 218 tys. (Cudzoziemcy, 2013-2016).

Oczywiście rejestracja oświadczenia nie jest równoznaczna z podjęciem zatrudnienia. Z drugiej strony nie wszystkie osoby podejmujące pracę w Polsce korzystają z systemu oświadczeń. Krótkookresowa migracja zarobkowa (najczęściej do 5 miesięcy) oraz mało efektywny system kontroli strumieni migracyjnych sprawiają, że stosunkowo łatwo jest przeniknąć do gospodarki nieformalnej w Polsce. Według wyliczeń Zakładu Ubezpieczeń Społecznych z 2017 r. tylko ok. 300 tys. osób z Ukrainy (co czwarta), opłacało składki ubezpieczeniowe. Pozostali pracowali na czarno lub na umowę zlecenie. Sytuacja ta niesie ze sobą szereg niekorzystnych następstw, zarówno z punktu widzenia państwa, jak i samych zainteresowanych. Zaradzić temu ma planowane uruchomienie od 1 stycznia 2018 r. systemu rejestracji pracowników ze Wschodu podejmujących pracę w Polsce, który usprawni przepływ informacji między Państwową Inspekcją Pracy i Strażą Graniczną (Rzemek, 2017, s. 3). Najprawdopodobniej również w tym samym okresie zostaną wprowadzone nowe regulacje, które pozwolą podejmować w Polsce pracę obywatelom Ukrainy, Gruzji i Mołdawii nieposiadającym wizy Schengen, przekraczającym granicę w ramach obowiązującego reżimu bezwizowego.

Warto podkreślić, że Polska nie jest jedynym państwem, do którego emigrują Ukraińcy. Szacuje się, że we Włoszech żyje obecnie 226 tys. osób pochodzenia ukraińskiego, w Republice Federalnej Niemiec ok. 200 tys., w Czechach 100 tys. (2016 r.), w Hiszpanii ok. 85 tys. (2014 r.), w Portugalii 41 tys. (2013 r.), w Grecji 17 tys. (2011 r.). Ukraińcy wyjeżdżają także poza Unię Europejską, głównie do Kanady, gdzie społeczność ukraińska liczy 1251170 osób (2011 r.) i Stanów Zjednoczonych z diasporą wielkości 931297 osób (2010 r.). Popularnym kierunkiem migracji tymczasowej jest również Turcja, którą w 2013 r. odwiedziło prawie 4 mln Ukraińców. Oczywiście część przyjechała tam w celach turystycznych, ale były także osoby, które znajdowały zatrudnienie w gospodarce nieformalnej, zajmując się drobnym handlem czy pracą w przemyśle erotycznym. Niestety nie jesteśmy w stanie precyzyjnie określić skali tego zjawiska (Fedyuk, Kindler, 2016, s. 4-195).

Ukraina jest obok Rosji największym państwem Europy Wschodniej, znajdującym się w trudnym położeniu gospodarczym, z tego też powodu generuje największe strumienie emigracyjne w regionie. Wcześniej głównym kierunkiem emigracji zarobkowej z Ukrainy była Federacja Rosyjska, jednak krwawy konflikt na wschodzie państwa przyczynił się do przekierowania części strumieni migracyjnych, których celem coraz częściej są państwa Europy Zachodniej. Podobny efekt, w dłuższej perspektywie czasu, będzie miało najprawdopodobniej także objęcie Ukrainy reżimem bezwizowym.

Analogicznie sytuacja wygląda w przypadku innych państw Partnerstwa Wschodniego objętych reżimem bezwizowym: Mołdawii i Gruzji, jednak ze względu na wielkość populacji tych państw wspomniane procesy nie mają tak masowej skali. W przypadku Mołdawii dochodzi dodatkowy czynnik, obserwowana tam od kilku lat masowa paszportyzacja: szacuje się, że prawie $1 \mathrm{mln}$ obywateli Mołdawii posiada obywatelstwo rumuńskie (Alarm, 2009). Przeciagający się kryzys ukraiński i brak widoków na 
poprawę sytuacji gospodarczej państw obszaru poradzieckiego będą zapewne w przyszłości zachęcały do wyjazdów na Zachód.

\section{Korzyści i zagrożenia płynące z migracji zarobkowej z Europy Wschodniej}

Rosnąca rok do roku migracja zarobkowa z Europy Wschodniej jest kolejnym wyzwaniem, z jakim prędzej czy później zmierzyć się będą musieli europejscy politycy. Już obecnie problem masowej emigracji Ukraińców na Zachód dotyczy nie tylko Polski. Pod wieloma względami sytuacja migracyjna Ukrainy przypomina położenie Polski z okresu po akcesji do Unii Europejskiej, z tą różnica, że póki co większość migrantów zarobkowych z Ukrainy to migranci tymczasowi lub cyrkulacyjni. Najczęściej wyjeżdżają za granicę na okres do 5 miesięcy, starając się do maksimum ograniczyć koszty życia na miejscu, tak aby możliwie duże środki transferować na utrzymanie gospodarstw domowych na Ukrainie. Podejmują z reguły nisko płatne prace, które znajdują się poza obszarem zainteresowania miejscowych, niejednokrotnie przenikają do gospodarki nieformalnej. Taki model migracji zarobkowej Marek Okólski nazywa migracją niepełną i możemy ją zaobserwować, analizując krótkoterminową migrację zarobkową Polaków do Niemiec (Kaczmarczyk, Okólski, 2008, s. 23-24).

Z punktu widzenia polskiej gospodarki Ukraińcy pełnią niezwykle istotną funkcję, ponieważ zapełniają wakanse na polskim rynku pracy powstałe w wyniku masowej emigracji zarobkowej po 2004 r. oraz niekorzystnych procesów demograficznych. Imigranci ze Wschodu nie stawiają zazwyczaj nazbyt wygórowanych żądań finansowych wobec pracodawców i godzą się na warunki, jakich nie chcą zaakceptować polscy pracownicy, podejmują z reguły pracę w rolnictwie, przetwórstwie rolnym, w budownictwie i usługach. Polscy pracodawcy najczęściej wypowiadają się pozytywnie o pracownikach ze Wschodu, doceniając ich zaangażowanie i pracowitość (Omachel, 2017).

Analizując najnowsze strumienie migracyjne ze Wschodu trudno oprzeć się refleksji, że Ukraińcy w Polsce pełnią analogiczną funkcję jak migracja zarobkowa z Europy Środkowo-Wschodniej w Niemczech czy Wielkiej Brytanii. Dzięki ich pracy możliwe jest utrzymanie dynamicznego tempa rozwoju gospodarczego, dodatkowo z reguły nie nadużywają oni sytemu socjalnego i ciężko pracują na swoje utrzymanie. Według wyliczeń Urzędu ds. Cudzoziemców zaledwie 1,8 tys. nowych imigrantów z Ukrainy korzystało z polskiej pomocy społecznej. Dodatkowo Ukraińcy bardzo dobrze integrują się ze społeczeństwem przyjmującym i ich obecność nie rodzi napięć na tle etnicznym. Wprawdzie masowy napływ taniej siły roboczej z kierunku wschodniego opóźnia tempo wzrostu najniższych wynagrodzeń, ale dzięki temu Polska gospodarka pozostaje w dalszym ciąu bardziej konkurencyjna. Dotychczas przybysze zza wschodniej granicy najczęściej znajdowali zatrudnienie w małych i średnich przedsiębiorstwach, jednak obecnie dostrzegalne jest rosnące zainteresowanie tą kategorią pracowników korporacji międzynarodowych. Coraz częściej do Polski przyjeżdżają także osoby dobrze wykształcone - według danych Ministerstwa Rodziny, Pracy i Polityki Społecznej liczba poszukujących pracy w Polsce specjalistów z Ukrainy wzrosła w latach 2013-2016 czterokrotnie. Z badań socjologicznych Otto Work Force wynika, 
że aż 94\% ankietowanych imigrantów z Ukrainy jest zadowolonych z pracy w Polsce, a co drugi chciałby pozostać tu na stałe. Co ważne, 96\% pytanych twierdzi, że Polska jest państwem otwartym na pracę cudzoziemców (Błaszczak, 2017).

Warto zauważyć także, że podejmujący zatrudnienie w Polsce imigranci ze Wschodu szybko integrują się ze społeczeństwem przyjmującym, przez co nie generują dodatkowych kosztów związanych z implementacją niezwykle kosztownej polityki integracyjnej. W zdecydowanej większości szybko uczą się języka polskiego, respektują miejscowe normy prawne i obyczaje, ale także sprzyjają wzrostowi wymiany handlowej między państwem imigracyjnym a emigracyjnym - część zarobionych pieniędzy przeznaczają bowiem na zakup miejscowych towarów, które w ten sposób stopniowo stają się coraz bardziej popularne na Wschodzie (Gorczyca, 2016).

Polska jest także popularnym kierunkiem migracji edukacyjnych z kierunku wschodniego. Najczęściej na studia przyjeżdżają do Polski także młodzi Ukraińcy. Według badań GUS w 2016 r. studiowało ich w Polsce 35 584, kiedy jeszcze w 2013 r. było ich zaledwie 13123 (Dane, 2013-2016). Przy czym warto zauważyć, że według wyliczeń NBP z 2015 r. aż 57\% studentów z Ukrainy deklarowało chęć podjęcia pracy w czasie studiów, najczęściej udaje im się znaleźć pracę dorywczą (Chmielewska, Dobroczek, Puzynkiewicz, 2016, s. 28).

Polskie doświadczenia z migracją zarobkową z Europy Wschodniej są zdecydowanie pozytywne. Imigranci ekonomiczni z Ukrainy i innych państw regionu zazwyczaj dobrze odbierani są przez społeczeństwo, szybko dostosowują do nowych warunków i nie generują problemów z punktu widzenia bezpieczeństwa publicznego. Poważnym wyzwaniem jest jednak duży odsetek osób, które podejmują pracę w gospodarce nieformalnej, przez co stają się łatwym celem zorganizowanej przestępczości, wykorzystywani do pracy niewolniczej lub w przemyśle erotycznym.

Kolejnym problemem może być postępujący proces osiedlania się na stałe gastarbeiterów ze Wschodu, co może z czasem rodzić napięcia na tle etnicznym podobne do obserwowanych obecnie w Wielkiej Brytanii. Ten proces może nasilić zjawisko formalizowania zatrudniania gastarbeiterów ze Wschodu. Konflikty mogą być podsycane przez rysujące się na horyzoncie różnice polityczne oraz odmienną wizję wspólnej przeszłości, która szczególnie wyraźnie rysuje się w toku dyskusji o roli Polaków w historii Europy Wschodniej, a w kontekście ukraińskim najwięcej kontrowersji budzi ocena działalności OUN i UPA-B.

\section{Wnioski}

Sytuacja demograficzna przeważającej części państw Europy sprawia, że chcąc utrzymać dotychczasowe tempo rozwoju gospodarczego, a przede wszystkim wysoki standard życia, większość państw regionu otwiera się na imigrantów zarobkowych napływających przede wszystkim z Południa. Masowa imigracja ze Wschodu, początkowo głównie z Europy Środkowej, jest zjawiskiem stosunkowo nowym, które przybrało na sile wraz z upadkiem, ,żelaznej kurtyny”. Początkowo miała ona przeważnie charakter migracji cyrkulacyjnej, dopiero z czasem niektórzy tymczasowi gastarbeiterzy decydowali się na osiedlenie na stałe. Podobne procesy obserwujemy obecnie, badając 
zjawisko imigracji zarobkowej z obszaru poradzieckiego. Przybysze z Ukrainy, Mołdawii i Białorusi koncentrują się przede wszystkim na możliwie szybkim zarobieniu dużej kwoty pieniędzy, które w przeważającej części wydane zostaną na utrzymanie gospodarstw domowych w państwie emigracyjnym, jednak w perspektywie kilkunastu lat sytuacja ta może ulec podobnym zmianom.

Wspomniana prawidłowość obserwowana jest w Europie od dziesięcioleci. Większość państw imigracyjnych musi zdawać sobie sprawę z ograniczonych możliwości kształtowania strumieni migracyjnych w realiach państwa demokratycznego, rygorystycznie przestrzegającego prawa międzynarodowego. $Z$ tego powodu niedobory siły roboczej najlepiej uzupełniać sprowadzając imigrantów z kierunków, jakie generują najmniej szeroko rozumianych kosztów z punktu widzenia państwa przyjmującego. Pod tym względem imigranci zarobkowi zza wschodniej granicy UE stanowią jedną z najbardziej pożądanych kategorii pracowników. W ogromnej większości szybko integrują się ze społeczeństwem przyjmującym, ciężko pracując na swoje utrzymanie, rzadko nadużywają dobrodziejstw systemu opieki społecznej i nie wiążą się z ugrupowaniami ekstremistycznymi i radykalnymi. Oczywiście problemem jest dość powszechne podejmowanie zatrudnienia $\mathrm{w}$ gospodarce nieformalnej, $\mathrm{z}$ tego też względu popularne są wśród tej kategorii imigrantów państwa i branże, gdzie szara strefa jest zjawiskiem dość powszechnym, jednak w ogólnym rozrachunku koszty gospodarcze i społeczne ponoszone z tytułu sprowadzenia tej kategorii pracowników są stosunkowo małe.

Imigracja z Europy Wschodniej jest najbardziej obiecującą formą uzupełniania niedoborów demograficznych starzejących się społeczeństw europejskich. Należy jednak pamiętać, że większość państw regionu Europy Wschodniej boryka się obecnie z poważnym załamaniem demograficznym, $\mathrm{z}$ tego powodu ich potencjał migracyjny jest stosunkowo niewielki i nie są one w stanie w pełni zaspokoić potrzeb na siłę roboczą państw Unii Europejskiej. Z tego też powodu obawa przed masową imigracją z Europy Wschodniej jest nieuzasadniona.

\section{Bibliografia}

Alarm at EU passports for Moldova, BBC News, 4.05.2009.

Balicki J., Stalker P. (2006), Polityka imigracyjna i azylowa. Wyzwania i dylematy, Wydawnictwo Uniwersytetu Kardynała Stefana Wyszyńskiego, Warszawa.

Banaś M. (2010), Szwedzka polityka integracyjna wobec imigrantów, Wydawnictwo Uniwersytetu Jagiellońskiego, Kraków.

Błaszczak A. (2017), Ukraincy coraz lepiej czuja się w Polsce, ,Rzeczpospolita”, 30.04.2017, http:// www.rp.pl/Gospodarka/304209954-Ukraincy-coraz-lepiej-czuja-sie-w-Polsce.html\#ap-1.

Brzozowski J. (2011), Polityka migracyjna Unii Europejskiej: stan obecny i perspektywy, „Studia Europejskie", nr 3.

Castles S., Miller S. J. (2011), Migracje we wspótczesnym świecie, przeł. A. Gąsior-Niemiec, PWN, Warszawa.

Chmielewska I., Dobroczek G., Puzynkiewicz J. (2016), Obywatele Ukrainy pracujacy w Polsce - raport z badania. Badanie zrealizowane w 2015 r., Departament Statystyki NBP, Warszawa.

Cudzoziemcy pracujacy w Polsce - statystyki, Ministerstwo Rodziny, Pracy i Polityki Społecznej, dane za 2013-2015 r., https://www.mpips.gov.pl/analizy-i-raporty/cudzoziemcy-pracujacyw-polsce-statystyki. 
Dane wstępne dotyczqce szkolnictwa wyższego, GUS, 2013-2016.

Dearden L. (2016), UK migration: Six myths about immigration debunked as latest figures show fall in non-EU arrivals, „The Independent”, 25.02.2016.

European Neighbourhood Policy. Southern Neighbourhood - migration issues, Briefing, December 2015, European Parliament, http://www.europarl.europa.eu/RegData/etudes/ BRIE/2015/573888/EPRS_BRI(2015)573888_EN.pdf.

Fedyuk O., Kindler M. (eds) (2016), Ukrainian Migration to the European Union. Lessons from Migration Studies, Springer Open, Warsaw.

Gorczyca A. (2016), Ukraińcy na zakupach w Polsce. Zostawiaja miliardy złotych, „Wyborcza. biz”, 29.08.2016, http://wyborcza.biz/biznes/1,100896,20612105,ukraincy-na-zakupach-wpolsce-zostawiaja-miliardy-zlotych.html?disableRedirects=true.

Kaczmarczyk P., Okólski M. (red.) (2008), Polityka migracyjna jako instrument promocji zatrudnienia i ograniczania bezrobocia, Ośrodek Badań nad Migracjami WNE UW, Warszawa.

Leman J., Janssens S. (2015), Human Trafficking and Migrant Smuggling in Southeast Europe and Russia Learning Criminal Entrepreneurship and Traditional Culture, Palgrave Macmillan, New York.

Neyer G., Andersson G., Kulu H. (2013), The Demography of Europe: Introduction, w: The Demography of Europe, red. G. Neyer, G. Andersson, H. Kulu, L. Bernardi, Ch. Bühler, Springer, New York-London.

Omachel R. (2017), Cała prawda o ukraińskiej imigracji, „Newsweek”, 30.04.2017, http://www. newsweek.pl/swiat/spoleczenstwo/imigranci-z-ukrainy-jakie-korzysci-ma-z-nich-polska,artykuly,409515,1.html.

Rau R., Muszyńska M. M., Vaupel J. W. (2013), Europe, the Oldest-Old Continent, w: The Demography of Europe, red. G. Neyer, G. Andersson, H. Kulu, L. Bernardi, Ch. Bühler, Springer, New York-London.

Romagnoli A., Mengoni L. (2013), The Economic Development Process in the Middle East and North Africa, Routledge.

Rzemek M. (2017), Nowe zasady zatrudniania Ukraińców, „Rzeczpospolita”, 15.03.2017.

Stosunek Polaków do przyjmowania uchodźców (2017), Komunikat z Badań nr 1, CBOS, styczeń 2017.

Szabaciuk A. (2016), Wpływ kryzysu ukraińskiego na procesy migracyjne na obszarze posowieckim, „Rocznik Instytutu Europy Środkowo-Wschodniej”, nr 5.

Szabaciuk A. (2014), Wybrane problemy polityki imigracyjnej Federacji Rosyjskiej, „Rocznik Nauk Społecznych KUL”, t. 6(42), nr 3.

The Future of World Religions: Population Growth Projections 2010-2050. Why Muslims Are Rising Fastest and the Unaffiliated Are Shrinking as a Share of the World's Population, Pew Research Center, April 2015.

Townsend R. M. (2015), The European Migrant Crisis, AMF Publishing, Shipley.

UN international migration report 2015: Highlights (2016), United Nations, New York.

Wejkszner A. (2014), Ewolucja zagrożenia dżihadystycznego w Europie, „Przegląd Strategiczny”, $\mathrm{nr} 7$.

World Values Survey (2005-2009), Crossings by country, Study \#906-WVS2005, v.2015.04.18, http://www.worldvaluessurvey.org/WVSDocumentationWV6.jsp.

World Values Survey (2010-2014), Crossings by country, Study \#906-WVS2010, v.2015.04.18, http://www.worldvaluessurvey.org/WVSDocumentationWV6.jsp.

Танги А. (2012), Великая Миграция: Россия и Россиянине после падения железного занавеса, Росспен, Москва.

Федеральный закон от 28.12.2013 N 389-ФЗ „О внесении изменений в статью 27 Федерального закона «О порядке выезда из Российской Федераиии и въезда в Российскую Федера- 
иุию» и стают Федерального закону «О правовом положении иностранных граждан в Российской Федерациии»".

\section{Streszczenie}

Celem artykułu jest analiza sytuacji migracyjnej Unii Europejskiej w kontekście procesów społeczno-politycznych obserwowanych w najbliższym sąsiedztwie zjednoczonej Europy. Przybliżymy w skrócie podstawowe wyzwania, z jakimi zmierzyć się musi obecnie Unia Europejska, w kontekście masowego napływu imigrantów/uchodźców z Południa, naświetlimy mało znany problem migracji zarobkowych z państw obszaru poradzieckiego oraz podejmiemy próbę oceny potencjalnych skutków wspomnianego zjawiska.

Słowa kluczowe: Unia Europejska, migracje, Europa Wschodnia, Federacja Rosyjska, Ukraina

\section{Migrations from Eastern Europe - opportunities and threats to the European Union}

\section{Summary}

The aim of the article is to analyse the migration situation of the European Union in the context of social-political processes observed in the immediate vicinity of the united Europe. We will briefly outline the key challenges facing the European Union in the context of the massive influx of immigrants / refugees from the South, highlighting the little-known problem of labour migration from the post-Soviet states and attempting to assess the potential impact of this phenomenon.

Key words: European Union, Migration, Eastern Europe, Russian Federation, Ukraine 